to bring a new drug into therapeutic use. The very fact that interferon has become such a powerful focus of public interest provides the professional community with a valuable opportunity for public enlightenment.

To be sure, the enlightenment will not be comfortable news for all those who receive it. Some will learn that they may be denied the chance to benefit from some innovation. It is however entirely consistent with the temper of the times that people should have to learn to live with the painful knowledge that what happens to them, literally their fate, may be intrinsically determined by chance. Curiously enough, people were more ready to accept this hard truth in mediaeval times, no doubt because of their common conviction that heaven was, in any case, a better place. Now that circumstances have changed, more robust philosophies are needed. It would be unfair to ask that physicians alone should shoulder the whole burden of helping their patients to come to terms with unlucky chance - but it would be wrong of them, and a disservice to their craft, if they were to fudge the issue.

As it happens, recent professional practice leaves very little to be asked for. The Medical Research Council, commenting last week on the report by Dr David Sacher and Professor D.C. Burke (Nature, 12 June) that it has been possible to prepare monoclonal antibodies against human interferon which may be of service in the preparation of pure material, did not flinch from using the phrase "possible anti-tumour activity" but went on to refer to the urgent need "to test whether interferon really is useful in the treatment of any or all cancers'. The Imperial Cancer Research Fund, which announced last week the allocation of $£ 1$ million to a clinical trial with interferon in the next two years, made very similar noises. In the past few weeks, most newspapers have similarly behaved sensibly and properly, mentioning the "possible anti-tumour activity" of interferon only with a warning that the case has not been established. That is how it should be. In this day and age, it would be ridiculous to conceal the promise simply because the promise has not yet been substantiated, just as it would be irresponsible to pretend that interferon has already been shown to be beneficial. It is also essential that everybody should understand that interferon may yet turn out to have no role in the treatment of cancer of any kind. Or it may simply be another anti-tumour agent.

\title{
Can DNA properly be called selfish?
}

The response to the articles which appeared earlier this year on the theme of "selfish DNA" (Doolittle and Sapienza, Orgel and Crick, Nature, 17 April) has understandably been voluminous; the notion is, after all, midly shocking. In essence, the authors are concerned to account for the presence in eukaryotic cells of much DNA that appears to have no function - the so-called "junk" DNA. They note that DNA sequences - any DNA sequences are above all capable of replication; that the environment of the cell nucleus is well-suited to such replication; and that once a DNA sequence has been incorporated into the eukaryotic genome, there is no particular mechanism by means of which it can be got rid of. So, the argument goes, if there are DNA sequences which, because of their structure, are incorporated into the genome more easily than other sequences, they will tend not merely to stay there but to multiply, at least until the metabolic burden of replicating all this functionless DNA at every cell division becomes too great. This is selfish DNA - and the batch of comments on the subject which appears on pages 617-620, mostly approving of the notion as a stimulating idea, shows that not everybody accepts that something like this goes on in molecular evolution. Indeed, both the comments now published, and the general gossip about selfish DNA that there has been, suggest that people are uneasy about the concept.

Part of the trouble is undoubtedly semantic. Implicitly at least, people appear to be asking (among other questions) whether, and if so in what circumstances, it can be proper to attribute to a class of molecules the property of selfishness. For are we not told, from a quite tender age, that we should avoid anthropomorphism like the plague? And while it may be proper to extend the notion of selfishness, originally intended as an attribute of individual human beings that distinguished them from others, to animate species as a whole, is it not misleading to call a class of mere molecules "selfish"? Certainly the usage goes against the grain. No doubt if somebody could think of a better word, everybody would use it. Yet the image is defensible.

First, if it is at all acceptable that the word "selfish" should be applied to the behaviour of a species in, say, its competition with another, who is to say that it should not also apply to the competition of one species of DNA molecule with another? Nobody, of course, pretends that DNA molecules are in themselves living things; in present circumstances, DNA molecules cannot replicate unless they are made up into intact organisms of some kind, virus particles at the simplest. But it would be excessively pedantic to ignore the sources of the concept now advanced, and in particular the way in which it has emerged from the studies intended to throw light on the origin of life (in which Orgel is one of the outstanding exponents), and which have plausibly suggested that in the primaeval soup, as it is called, the course of molecular evolution may have been determined by competition between different species of RNA molecules. The authors of the concept of selfish DNA might fairly ask how, in such circumstances, the concept of life as such is to be defined? And if the word "selfish" can be applied to a contemporary species in competitive evolution with others, why should it not also be applied to molecules in competitive molecular evolution? If there is an error, it is in the use of "selfish" in any but its original meaning.

The second justification of the use of "selfish" applied to DNA is the prior use of the word in relation to a gene. Thus Dawkins, in 1976, used the title "The Selfish Gene" for his account of how it appears that the effect of natural selection is to favour favourable genes and not strictly the organisms which carry them. This is, of course, a contentious field. The familiar aphorism that "the organism is DNA's way of making more DNA" may turn out to be more than a mere joke, but whole-organism biologists find it offensive. In the present argument about selfish DNA, however, the use of "selfish" is justified on literary grounds: in a field in which many people are familiar with at least the title of Dawkins's book, to apply the same word to DNA suggests graphically what the authors are driving at. Is that not how the language itself evolves?

None of this constitutes a licence for the use of anthropomorphic words wherever and whenever they have some suggestive or figurative value. It is, indeed, to be hoped that the word "selfish" will wither away once people have grasped the point that Doolittle and Sapienza and Crick and Orgel are trying to make. On present form, that may take some time. The question of whether they are right or wrong is clouded by other semantic issues. Is it, for example, proper to use the term "natural selection" to refer to the preferential emergence of some species of nucleic acid molecule either in the primaeval soup or in the environment of the eukaryotic nucleus? Part of the trouble is that natural selection is synonymous with Darwinian selection but selfish DNA has Lamarckian tendencies. Unfortunately the neutral word "selection" is not a sufficient substitute, implying as it does that the selection is undertaken by some unspecified agent; "to be selected", on the other hand, is clumsy and only strengthens the habit of writing in the passive. This, however, is a minor issue compared with the way in which "selfish" appears to have provoked in many people's minds, almost by free association, the belief that the selfish DNA must be the antonym of "altruistic DNA" and that the questions now raised are somehow linked with those which keep sociobiologists busy at public speaking. That is a cruel misfortune. 